\title{
Features of Educational-Oriented Environment of a Higher Educational Institution
}

\author{
Yoldyz N. Ganieva
}

Institute of Technology Branch of Ulyanovsk State Agricultural Academy named after P. A. Stolypin, 433511, Dimitrovgrad, Russia.E-mail: yoldyz.ganieva@mail.ru

Elena V. Makarova

Ulyanovsk State Agricultural Academy named after P. A. Stolypin, 432063, Ulyanovsk, Russia

Tatyana V. Levchenkova

Russian State University of Physical Education, Sport, Youth and Tourism (SCOLIPE), 105122, Moscow, Russia

Sardana I. Kolodeznikova

Svetlana G. Ushkanova

Ulyana P. Buldakova

North-Eastern Federal University named after M.K. Ammosov, 677000, Yakutsk, Russia

Guzel B. Sayfutdinova

Kazan State Power Engineering University, 420066, Kazan, Russia

Doi:10.5901/mjss.2015.v6n6s2p519

\section{Abstract}

\begin{abstract}
Understanding of new guidelines in professional education has led to the need to update its content in terms of educationaloriented environment of high school, contributing to the formation of a competent graduate. In this regard, this article aims to identify the characteristics of the educational-oriented environment of professional institutions. A leading approach to the study of this problem is an integrative approach that performs a strategic function between the processes of training and education of future competent professionals. The article reveals the features of educational-oriented environment of professional institutions, namely the diversification of various innovative forms of educational work in the University; special training and retraining of teachers to meet modern requirements to professional education; the development of the social relations of the educational environment involving participation in the processes of training and education of social partners and potential employers; updating of training and education technologies, etc. The materials of the article are of practical significance for the faculty of educational institutions of professional education.
\end{abstract}

Keywords: educational-oriented environment, peculiarities, high school, students.

\section{Introduction}

Analysis of the factors of youth professional socialization in the labor market shows that in modern conditions for a considerable part of the respondents the value of labor is determined by the amount of wages and the possibility of personal self-realization in professional activity. The youth education is seen not only as a just acknowledgement of their abilities and talents, but also as a resource in the struggle for higher social status. In this context, vocational education in high school should be considered as an important component of the whole system of training providing with a successful career of future competent professionals.

Educational environment of higher educational institutions of professional education is an integrative wholeness, which can be structured with a selection of multiple levels of its organization as their dynamic integrity; as a set of built according a concentric principle components (educational environment of the faculty, Department, course, group); as a 
spiritual community that occurs in the inter - subjective interaction and contributing to the socio-professional development of future competitive specialist. Educational environment brings together in one process two main subsystems - learning and training, thereby integrating all the teachers influence on the identity of the student (Maslennikova, 2004a; Maslennikova, 2004b; Abulkhanova, 2005; Leont'ev, 1996; Abolin, 2007, etc.). This integration occurs through the inclusion of special educational topics in the courses of lectures, seminars etc. of professional and special disciplines' cycles; the inclusion in the curricula of professional and creative tasks and activities of a research nature; design and implementation by students of business projects; inclusion in the educational process of personality-centered technologies, individual working methods, contributing to the maximum extent to take into account the abilities, aptitudes and interests of each student; the introduction of electives and courses on choice; conducting of courses and seminars on topical educational issues of aesthetics, national and world culture, psychology of communication and communicative culture, ethics, health culture and socio-legal problems.

\section{Methods and Methodology}

The study aims to identify the characteristics of the educational-oriented environment of professional institution that contributes to the expansion of students' social relations in their academic and extra-curricular activities. This educational environment increases the possibility of its members' self-realization.

Methodological basis in the development of this problem were the following statements:

- the education system consists of four main components: educational and humanistic potential of basic educational curricula of higher professional education; educational patterns and events; students; staff of educators (Shaidullina et al., 2015);

- like any system it can be described with the help of a generalized number of objective characteristics (parameters), the accumulation of which can significantly improve the efficiency and quality of educational activities;

- assessment of the quality of education must be applied consistently throughout the period of study at the University in respect of students, and in relation to the activities of educational institutions;

- evaluation of University educational potential and level of students' education should be carried out in accordance with the various areas of education and in accordance with the basic indicators of an estimation;

- a mandatory element of the assessing technology of students' education quality should be the revealing of their "starter" personality characteristics.

\section{Results and Discussions}

\subsection{The structure of the educational environment of the University}

A wide network of forms of educational work in higher educational institution of professional education, in addition to meeting educational or creative interests of students, contributes to the expansion of the scope of the relationship, because often the team circle, club and sections are for people of different ages, and in some of them young teachers spend their leisure time too. This staff increases the possibility of self-realization of every its members. The feature of activity of these groups is that they are joined in a united designed educational environment (Fig. 3). 


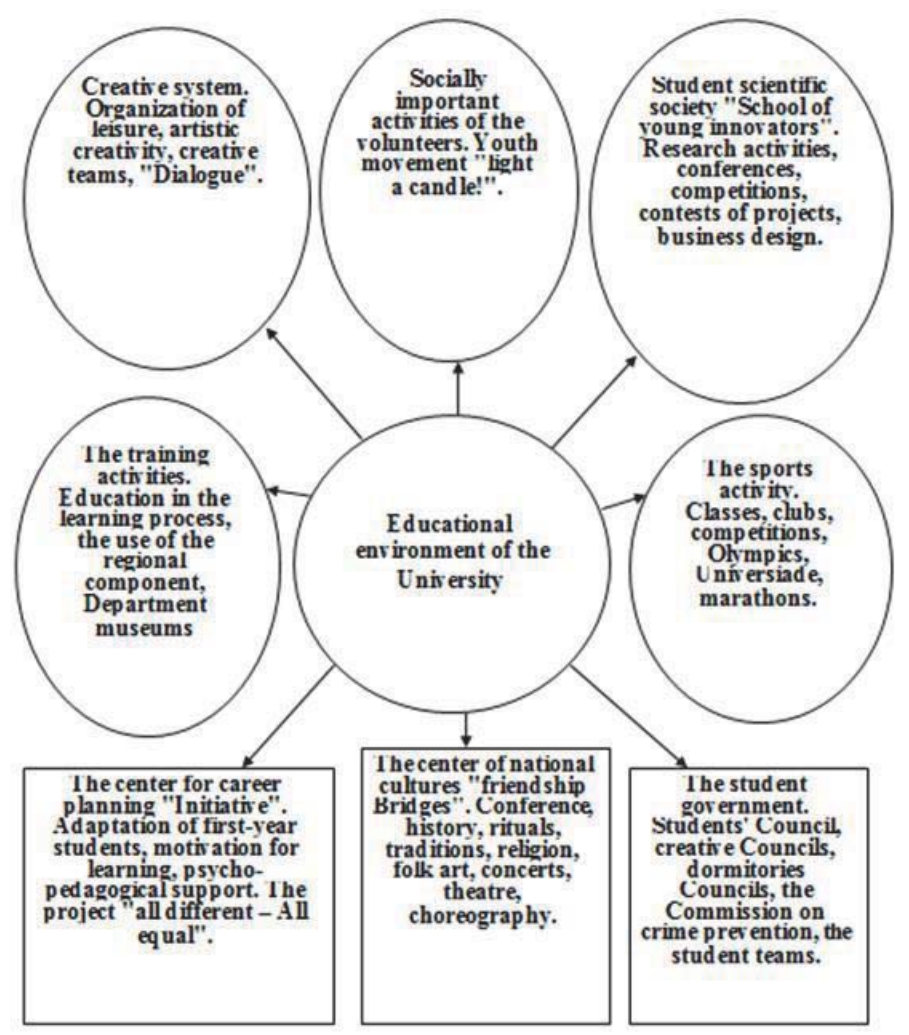

Figure 1. The structure of the educational environment of the University

\subsection{The control system of educational influences in high school}

Environment as a relatively stable set of personality elements that surround a person, directly affects the process of socialization and individualization, and the criteria for its effective impact on each person is the functioning of the University as Corporation, as an open system, a communication center and a healthy lifestyle. To this contributes the existing University management system of educational influences, which combines the pedagogical impact and the government of education's entities. For example:

1. "Management school" of the University provides extension of the "leadership field". Students are given the opportunity to learn management processes and procedures in as conditions which are close as possible to reality, to obtain a specific product of the activity (project). In these conditions, they are evaluated not only as student activists, who possess managerial skills, but also as leaders who perform their social roles and maximize the leadership potential (Mukhametzyanova, 2009);

2. The use of social and pedagogical projects' innovative technologies in the activities of the student government helps to create optimal conditions for the students' fulfillment of different roles and functions, their realization of "self"- abilities and develop the necessary skills of social interaction (Oskarsson, 2004). Student government is represented by such public organizations as: the Student Council, the primary trade Union organization of students and postgraduates, the Russian youth Union and the Russian Union of rural youth. The main objective of all organizations is to create conditions for the successful self-realization of socio-cultural identity in the process of higher vocational training (Mukhametzyanova, 2005a; Zeer, 2005a; Klimova, 2003; Mitina, 1998)

3. The student Council of the University, despite of the fact that it is a very young organization, is one of the fastest growing youth organizations of student government, operating on the territory of the University. One of 
its main principles is the innovation in solving the problems, including the search for and support of the most creative, talented student youth representatives who can not only propose, but also to act (Mukhametzyanova, 2005b; Zeer, 2005a; Zeer, 2005b). Student Council in high school combines the councils of the faculties and dormitories, the councils of the faculties in their turn work with the heads of study groups, in the Dorm - with the heads of dormitories. The student Council operates in the following areas: students' cultural leisure (development of students ' moral, social maturity and responsibility); sports activities (students' involvement in active physical training and sports, healthy lifestyle, care of their own health, its protection and defense).

\subsection{Management components to develop the process of university students' social activity}

The main components to manage the process of university students' social activity are:

- Creation of optimal logistical, social, moral and psychological conditions, in which the social qualities of the individual student are formed;

- Meaningful impact on the processes to form the worldview, moral values and attitudes, socially important needs and motives of activity of young people;

- Direct control of the behavior of young people, including the organization, management, control of their activity.

Managing of the students' activity development reaches the goal only if it is fixed in specific organizational forms of educational institutions' educational system. The entity of management can be as institutionalized (structural departments of the University of the corresponding profile, public associations, collectives of students and teachers) so individual (person, endowed with a certain amount of power). The activity of each entity of educational activity at the University is formalized by relevant normative documents approved by the management bodies of the agricultural Academy ("Regulation about the Pro-rector on educational work", "Regulation about curator of the student group", "regulations on creative system", "School of young innovators", etc.)

\subsection{The concept of educational activity of the Ulyanovsk state agricultural Academy after P. A. Stolypin}

The main difficulty of management in development of student youth social activity is that here it is assumed the impact on the subjective world of a young man who is characterized by uniqueness, the individuality and peculiarities. It is necessary to analyze the levels' conditions of its development, to take into account the changes taking place in the "object" of education, and to adjust the methods and to develop innovative technologies for the management influence (Nezvankina, 2004; Osipov, 2003; Osipov, 2004; Shabunina, 2001a; Shabunina, 2001b; Asyanov, 2000; Klimova, 2003).

The efforts of all the entities of management aims at encouraging students to take an active social life activity with their first year of study at the Academy, to arouse their interest in participating in a variety of affairs, thereby ensure the formation of their personal and civil maturity. Conceptual approaches to the organization of this activity are reflected in the concept of educational activity of the Ulyanovsk state agricultural Academy after P. A. Stolypin.

When creating a concept that represents a science-based set of views on the basic principles, goals, objectives, content and direction of development of extra-curricular activities' system at the Academy, the following provisions were taken into account:

- The Academy can build up its educational activities only on the basis of the principles of expediency, historicism, differentiation and integration, continuity, comprehensiveness, allowing its organization to perform socially important functions - cultural and educational, organizational and managerial, regulatory and educational, communicative, socio-translational, social and integrative, as well as the functions of selfdevelopment and social inheritance of self-realization.

- As a social Institute the Academy is to implement its functions in the formation of socially mature citizens, educated and trained people through the interaction of teachers and students within the academic and extracurricular activities, while each party has a common goal, roles and expectations as well as a social status.

- Like any educational institution, the Academy exists in a specific historical social environments and its activity is determined by sociocultural factors - the level of public consciousness, the state of public morals, science, and other social institutions.

The Concept identifies the following criteria for assessing the quality of students' education. 
Table 1. Criteria for assessing the quality of students' education

\begin{tabular}{|c|c|}
\hline № & Criteria \\
\hline 1. & Educational and humanistic potential of educational curricula \\
\hline 1.1 & $\begin{array}{l}\text { The availability of additional humanitarian and the selection of courses, seminars, etc., having an educational, humanistic } \\
\text { and personal developmental direction. }\end{array}$ \\
\hline 1.2. & $\begin{array}{l}\text { The availability in the universities of the modern psychological-pedagogical technologies of education, student support and } \\
\text { personal development. }\end{array}$ \\
\hline 1.3. & $\begin{array}{l}\text { The availability of educational-methodical manuals on the development of cognitive abilities, professional motivation and } \\
\text { direction, professionally important qualities, logical and creative thinking, attention and memory in the high school. }\end{array}$ \\
\hline 1.4. & The availability of alternative educational curricula for the most gifted students. \\
\hline 1.5. & $\begin{array}{l}\text { The level of requirements' development to the personal characteristics of the individual (in } 2009 \text { was replaced the level of } \\
\text { readiness of competencies' certificates, relevant to improving the students' education). }\end{array}$ \\
\hline 2. & Educational structures and activities \\
\hline 2.1. & $\begin{array}{l}\text { Availability, scope and effectiveness of artistic, scientific, sports and other extra-curricular student educational agencies } \\
\text { (creative teams, groups, clubs, sections, centers, etc.). }\end{array}$ \\
\hline 2.2. & Organizing of educational events in the University in the main areas of educational activities. \\
\hline 2.3. & The availability of departments to manage education (University, faculty, etc.). \\
\hline 2.4. & $\begin{array}{l}\text { The availability in the universities of the student government and other institutions of students' self-organization (public } \\
\text { organizations, associations). }\end{array}$ \\
\hline 2.5 . & The availability of psychological counseling service in the university. \\
\hline 2.6. & The level of formation of socio-cultural environment of the University. \\
\hline 2.7. & Nomenclature of university's regulatory and guidance documents regulating educational activities. \\
\hline 2.8. & The availability of Univer \\
\hline 3. & Personnel p \\
\hline 3.1. & Special training of specialists for \\
\hline 3.2 & $\begin{array}{l}\text { Characterization of the moral, ethical and cultural level of the teachers and employees of extracurricular educational } \\
\text { departments of the University. }\end{array}$ \\
\hline 3.3 . & The use of the humanistic, individually oriented methods of work with students by the faculty of the University. \\
\hline 3.4 & The use of modern innovative pedagogical methods and tools for sth \\
\hline 3.5. & The participation of specialis \\
\hline 3.6. & $\begin{array}{l}\text { The inclusion in the curriculum on teachers' professional skills improvement of sections on the organization and content of } \\
\text { the educational activity. }\end{array}$ \\
\hline 3.7. & $\begin{array}{l}\text { Activities to improve the quality of educational activities of teachers in higher education (seminars, training, consultations, } \\
\text { etc.). }\end{array}$ \\
\hline 3.8. & Forms of educational activities experience's exchanges in higher education institutions. \\
\hline 4. & The level of students' education. \\
\hline 4.1. & $\begin{array}{l}\text { A person's awareness of the importance of citizenship standpoint, family relations, knowledge of legal responsibilities } \\
\text { towards the family. }\end{array}$ \\
\hline 4.2 & The formation of Patriotic, civic, responsibility, legal competence and obedience to the law. \\
\hline 4.3 & $\begin{array}{l}\text { Awareness of responsibility for the surrounding world, the preservation of the Earth, the formation of ecological } \\
\text { consciousness. }\end{array}$ \\
\hline 4.4 & Awareness of the essence and need of the chosen profession for social and economic development of the country. \\
\hline 4.5 & Willing of labor activity. \\
\hline 4.6 & $\begin{array}{l}\text { The possession of moral and spiritual ideals, the capacity for the formation and development of social, cultural and human } \\
\text { relations in accordance with universal values. }\end{array}$ \\
\hline 4.7 & $\begin{array}{l}\text { The possession of ability to form human relations in accordance with universal human values in professional, socio-cultural } \\
\text { and domestic life. }\end{array}$ \\
\hline 4.8 & The level of self-control and regulation of personality's activity and development. \\
\hline 4.9 & adiness to perform social functions and roles in professional, socio-cultural and \\
\hline & \\
\hline
\end{tabular}

Within the creation of educational-oriented environment in the Academy the following directions of work are organized:

1. The school of young innovators, the following tasks of which are highlighted: the popularization of science among the youth; expansion of innovative, research, professional and creative potential of young people.

2. The center "Initiative", the objectives of which are: support for temporary and permanent employment of the students of the Ulyanovsk state agricultural Academy named after P. A. Stolypin; attracting of students to 
participate in the labor activity; Patriotic education of youth; support and development of traditions; cultural and socially important activities among the population; assistance in the formation of personnel reserve for agriculture of the Russian Federation.

3. The center of leisure of youth, the tasks of which are the following: promotion of healthy lifestyle among adolescents and young people; formation of active civil standpoint, optimistic attitude to life as to human values; social service, the formation of psychological stability and prevention of addiction.

4. The project "Commonwealth", within of which operates a platform for communication "Dialogues" (joint discussion of student problems, perspectives, activities, initiatives with the student Council and the University administration, political religious leaders).

5. Center "Dialogue", which aims are: strengthening and development of educational functions of Ulyanovsk state agricultural Academy named after P. A. Stolypin, the enlargement of entities of education, coordination of their efforts; improving the social status of education in the education system in Ulyanovsk state agricultural Academy named after P. A. Stolypin.; the use of native traditions and modern experience in education; improving the culture of interethnic relations; the development of humanistic principles, contents and mechanisms of moral civic education

6. Contests for freshmen, "Hello, we are looking for talents!", "The day of Russian students", "Tatyana's day", "Valentine's Day", "defender of the Fatherland Day", "international women's day", the Amateur arts festival "Student spring" and "Student autumn", "Miss Academy", inner academic KVN League "Start", "Ropes course" - dedication to freshmen, sports and entertainment events: "the Hotel is my home", "Day of self-government", etc.

These events have a subjective impact on the education of students:

1. In the field of training and education:

- the acquisition of knowledge, abilities, skills in the chosen profession;

- implementation of research capacity;

- postgraduate training;

- development of skills to systems thinking, the ability to overcome stereotypes, development of activity, perseverance, diligence, ability to evaluate the need for different types of information for their own personal growth, the desire for creative self-realization, commitment to positive interaction and cooperation in the team; the formation of initiative, ability to work in team, ability to forecast and project activities;

- education of social activity, clarity of citizenship, tolerance, focus on a healthy lifestyle;

- development and realization of creative abilities, development of the ability to act independently in conditions of uncertainty, the desire for creative self-realization; willingness to positive interaction and cooperation in the team; the formation of initiative, ability to work in team, ability to forecast and project activities; optimism, faith in the success of the business, creativity, creative approach, professionalism, stress tolerance, ability to take risks, empathy, exactingness;

- development of physical abilities (ability of observation and analysis of the situation, the formation of readiness to control self-behavior, patriotism, optimism, civic responsibility, mobility, energy).

2. In the field of social protection:

- availability of medical care;

- housing provision;

- provide of fellowship;

- material support;

- support for student families.

The creation of educational-oriented environment of the Academy implies its organization by interacting levels:

- professionally and personality-forming level, regulated by principles, rules, implemented in academic and extra-curricular activities and expressed in the system of relations, creating psychologically comfortable moral spiritual environment;

- socio-civic level, characterized by different forms of student activism, developed civil and legal aspect of the concept of extracurricular activities as part of the educational process;

- household, behavioral, which is determined by the life of students, where an important role plays the subject 
and the external environment, aesthetic design, material environment, ritual and ethical livelihood, etc.

When creating an educational-oriented environment students' learning strategies of actively- transforming behavior, the creation by man himself of favorable conditions for the realization of their life goals with the formation of a specialist-professional were applied.

\section{Conclusion}

Thus, in the professional training of students at the University an important place is occupied by educational environment, which is an integral part of the educational process and contributes to the immersion of students in the specifics of professional activity. A wide network of forms of educational activities in higher education in addition to meeting educational or creative interests of students, contributes to the expansion of social relations due to the fact that they spend their leisure in mixed-age groups, ranging from students to young teachers. This staff increases the possibility of self-realization of each of its members. The feature of activity of these groups is that they are joined into united designed educational environment.

\section{References}

Abolin, L. M., Maslennikova V. S. \& Mukhametzyanova F. G. (2007). Raising of community-oriented person. Kazan: Publisher "Danis": IPPPORAO, 74

Abulkhanova, K. A. (2005). The principles of the entity in the national psychology. Journal of Higher School of Economics, 4, 3-21.

Asyanov, H. A. (2000). Organizational-pedagogical conditions of creation and functioning of the rural educational complex. Kazan: ASIC RAO, 20.

Klimova, I. K. \& Osipov P. N. (2003). The ratio of students to study in the agricultural school. Development of the student's personality colleges in the socio-cultural educational space. Kazan: ASIC RAO, 53-55.

Leont'ev, A. A. (1996). Pedagogical dialogue. Moscow: Publishing House center "El Fa", 93.

Maslennikova, V. S. (2004a). Methodological and theoretical foundations of education of students and university colleges in the modernization of education. Kazan: ASIC RAO, 148.

Maslennikova, V. S. (2004b). Modern ideology education of community-oriented person. Kazan, 176.

Maslennikova, V. S. (2007). Education community-oriented person. Kazan: Publisher "Danis", 68.

Mitina, L. M. (1998). Psychology of professional development of teachers. Moscow, Flint: SAG, 185.

Mukhametzyanova, G. V. (2005a). Questions of general and vocational pedagogy: Selected Works. Kazan, 447.

Mukhametzyanova, G. V. (2005b). Vocational education: problems of quality and scientific and methodological support. Collection of selected pedagogical works. Kazan, 360.

Mukhametzyanova, G. V., Morozova, G. N. \& Shigapova, L. P. (2009). The formation of leadership qualities of students of high school in the activities of government. Kazan, 46.

Nezvankina, Y. A. (2004). Reproduction in agriculture: problems and prospects. International scientific-practical conference. Penza, 132133.

Oscarsson, B. (2004). Basic skills as a compulsory component of high-quality vocational education. Moscow, 42.

Osipov, P. N. (2003). Peculiarities of students. Specialist agricultural college: 4, 30-31.

Osipov, P. N. (2004). Staff training for the village: how it will to be? Specialist: 6, 35-39.

Shabunina, V. A. (2001a). Humanization of training in educational process. Moscow, Publishing ICCA, 368.

Shabunina, V. A. (2001b). Pedagogical problems of humanization of education of students of agricultural high school. Monograph Moscow, 227.

Shaidullina, A. R., Evsyukova N. Y., Mikhailov V. A., Gazizova F. S., Masalimova A. R., Khairullina E. R. \& Galimzyanova I. I. (2015). The Curriculum Project on Professional and Pedagogical Teachers Communication Culture Formation. Mediterranean Journal of Social Sciences, 6(2 S3), 202-208.

Zeer, E. F. \& Symanyuk E. E. (2005a). Competence approach to the modernization of vocational Education in Russia. Higher education today: 4.

Zeer, E.F., Pavlov, A. M. \& Symanyuk, E. E. (2005b). The modernization of vocational education. Moscow: Univ. psihol.-social. Inst, 216. 